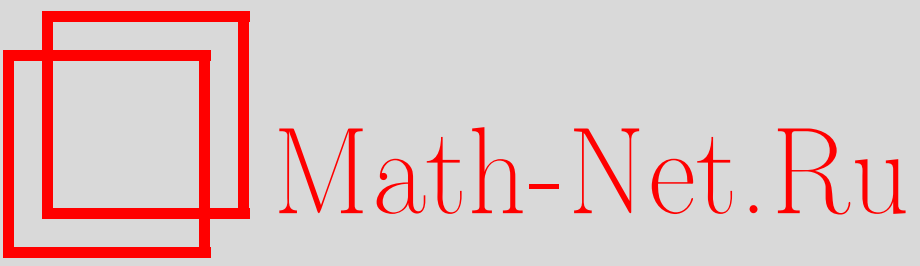

Петров В. В., Золотарев В. М., Пресман Э. Л., Боровков А. А. (юбилеи), Теория вероятн. и ее примен., 2011, том 56, выпуск 2, 373

DOI: https://doi.org/10.4213/tvp4380

Использование Общероссийского математического портала Math-Net.Ru подразумевает, что вы прочитали и согласны с пользовательским соглашением

http://www . mathnet.ru/rus/agreement

Параметры загрузки:

IP : 3.89 .197 .203

26 апреля 2023 г., 18:30:08 
ТЕОРИЯ ВЕРОЯТНОСТЕЙ

Том 56

И ЕЕ ПРИМЕНЕНИЯ

Выпуск 2

2011

(c) 2011 г.

В начале 2011 года мы отметили несколько

замечательных дат.

10 февраля 2011 года исполнилось 80 лет доктору физико-математических наук, профессору

Валентину Владимировичу Петрову,

27 февраля 2011 года исполнилось 80 лет доктору физико-математических наук, профессору

\section{Владимиру Михайловичу Золотареву,}

28 февраля 2011 года исполнилось 70 лет доктору физико-математических наук

Эрнсту Львовичу Пресману,

6 марта 2011 года исполнилось 80 лет академику

Александру Алексеевичу Боровкову.

Редакционная коллегия журнала

«Теория вероятностей и ее применения»

поздравляет своих юбиляров и желает им крепкого здоровья,

благополучия и дальнейших творческих успехов. 